\title{
The Stanford-U.S. Geological Survey SHRIMP Ion Microprobe- A Tool for Micro-Scale Chemical and Isotopic Analysis
}

\begin{abstract}
nswers to many questions in
Earth science require chemical analysis of minute volumes of minerals, volcanic glass, or biological materials. Secondary Ion Mass Spectrometry (SIMS) is an extremely sensitive analytical method in which a 5-30 micrometer diameter "primary" beam of charged particles (ions) is focused on a region of a solid specimen to sputter secondary ions from 1-5 nanograms of the sample under high vacuum. The elemental abundances and isotopic ratios of these secondary ions are determined with a mass spectrometer. These results can be used for geochronology to determine the age of a region within a crystal thousands to billions of years old or to precisely measure trace abundances of chemical elements at concentrations as low as parts per billion. A partnership of the U.S. Geological Survey and the Stanford University School of Earth Sciences operates a large SIMS instrument, the Sensitive High-Resolution Ion Microprobe with Reverse Geometry (SHRIMP-RG) on the Stanford campus.
\end{abstract}

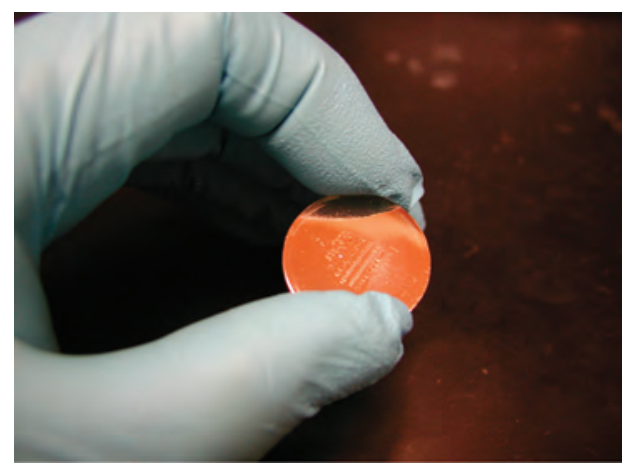

Specimen mount for the SHRIMP-RG with mineral grains embedded in epoxy resin, then ground and polished to expose interiors for analysis. The 1-inchdiameter disk has been coated with a thin layer of gold that conducts electricity.

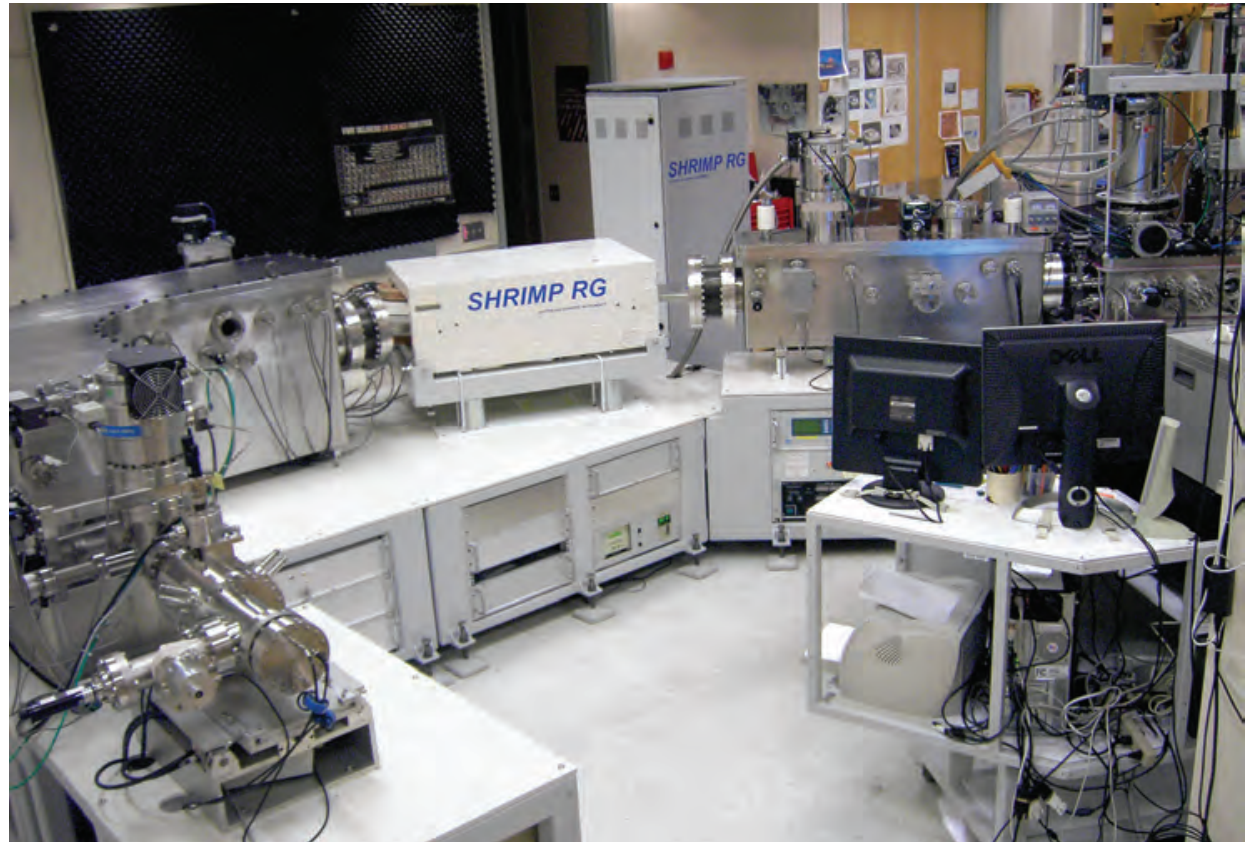

The Stanford-USGS SHRIMP-RG in the room constructed specifically for the instrument in the basement of the Green Earth Sciences Research Building, Stanford University. Control console is at right, behind two black computer monitors. Specimen chamber is at extreme right, behind the control console. The primary ion source is out of view behind the specimen chamber. Secondary ions sputtered from the specimen move from right to left through the doubly focusing mass spectrometer, which is maintained at high vacuum. The white "SHRIMP RG" object in the center of the image is the laminated electromagnet of the 1-m-radius magnetic sector. The large curved stainless steel box left of the magnet is the electrostatic analyzer of the 1.2-m-radius electrostatic sector. Mass- and energy-selected secondary ions are counted by an electron multiplier in the cylindrical device in the lower left foreground.

\section{Big Machines to Study Tiny Things}

The need to be able to separate a rare isotope from a nearby mass (abundance sensitivity) in a small sample and ability to resolve very small differences in mass in geoscience research have led to the development of large Secondary Ion Mass Spectrometry (SIMS) instruments. In geoscience labs around the world there are now approximately 30 such machines, with about equal numbers of

Australian-made SHRIMP and French-made CAMECA ion probes. Housed in the Stanford University School of Earth Sciences, the joint Stanford-U.S. Geological Survey (USGS) Ion Microprobe Laboratory operates a SHRIMP$\mathrm{RG}$ that is one of two in which the electro- static analyzer is positioned downstream of the 1-m-radius magnetic sector of the doubly focusing secondary ion mass spectrometer. This reverse geometry (RG) enables precise analysis at very high mass resolving power. Specimens are sectioned and polished grains cast in epoxy resin, natural grain surfaces positioned parallel to the mount surface by pressing grains into soft indium metal, or polished thin sections of rocks. Optical and scanning electron microscope (SEM) images are used to map and characterize the material to be analyzed. Specimens are coated with a thin layer of electrically conductive material such as gold to prevent charge build-up from the primary ion beam. Inside the high vacuum 
SHRIMP-RG, samples are manipulated by a digitally encoded mechanical stage that automatically drives to analysis locations on the specimen that are preselected by the scientist. During an analysis, the primary beam sputters a few atomic layers per second from the specimen in a 5-30 micrometer diameter spot. About 1-5 nanograms of material are removed during a typical 10-20 minute analysis. Very high resolving power for different masses is required because certain secondary ions produced during sputtering may interfere with the ions of interest. The SHRIMP-RG is capable of separating two adjacent masses by an amount ( 0.005 to 0.03 atomic mass units, depending upon mass range) that is sufficient for most applications without reducing the secondary ion beam intensity. Ion arrivals are detected at the end of the mass spectrometer by a sensitive counting system and converted

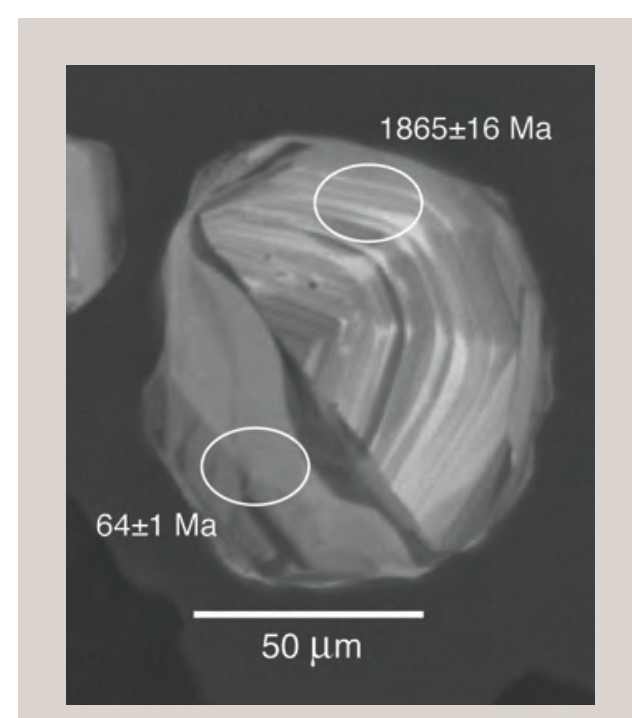

Uranium-Lead Geochronology of Zircon

Zircon crystal from andesite erupted from Redoubt Volcano, Alaska. Zircon was mounted in epoxy resin, ground and polished to expose interior, and imaged with a scanning electron microscope (SEM). Internal compositional variation is revealed by cathodoluminescence (CL), in which light emitted under electron bombardment is proportional to the amount of chemical impurities (trace elements) in the crystal. White ellipses indicate spots analyzed by SHRIMP-RG for uranium-lead (U-Pb) geochronology Ages are given in millions of years before present (Ma). Truncated CL banding in the upper right indicates that the older part of the crystal is a fragment of ancient zircon, while the more uniform $\mathrm{CL}$ in the lower left is a much younger overgrowth. Although recovered from a young volcanic deposit, this zircon crystal formed in rock beneath the volcano and gives unique information on the geologic history of the Alaska Peninsula. Scale bar is 50 micrometers $(\mu \mathrm{m})$ long. After Bacon and others (2012), figure 4B. to isotope ratios or elemental concentrations by comparison with similar measurements on reference materials (standards) of known composition. Development of new analytical techniques often demands identification and characterization of new standards.

\section{A Government-Academic Partnership}

The SHRIMP-RG at the Stanford-USGS Ion Microprobe Laboratory is the centerpiece of the Stanford-USGS Micro Analysis Center (SUMAC). SUMAC was initiated in the 1990's, and the SHRIMP has been operational since 1998. Scientists from USGS offices around the country visit the laboratory to analyze specimens in research supported by Mineral Resources, Geologic Mapping, Volcano Hazards, Climate, and other Geological Survey programs. Within USGS, the lab is organizationally housed under the Associate Director for Energy and Minerals, and Environmental Health Mission Area. On the Stanford side, faculty, students, and other researchers use the SHRIMP-RG for a wide variety of investigations. External researchers from within the United States and other countries also have access to the laboratory. External investigators pay a standard daily fee for analysis time; Stanford and USGS scientists pay a reduced daily fee that reflects the investment of the two organizations.

Although most external researchers are U.S. academics supported by the National Science Foundation, others have come from Canada, China, Taiwan, the United Kingdom, Israel, Russia, Brazil, and New Zealand. Research by these visiting scientists fosters innovative science, complements USGS and Stanford research programs, and builds the international reputation of the lab. To staff the lab, Stanford and USGS supply Co-Directors, Staff Scientists, and student assistants. An electronics technician is contributed by USGS, and space in the Green Earth Science Research Building is provided by Stanford. Income from fees covers spare parts and supplies, modifications to the SHRIMP-RG to improve performance, and partial salary support for a staff scientist.

\section{Geochronology}

The Stanford-USGS SHRIMP-RG has been intensely used for uranium-lead (U-Pb) geochronology since the instrument was installed in 1998. This versatile method exploits the slow radioactive decay of parent $U$ isotopes to daughter $\mathrm{Pb}$ isotopes as a natural clock for the time elapsed since crystallization of the material analyzed, from as little as a few hundred thousand years to zircons 4.5 billion years old recovered from meteorites. Uranium is present at tens to thousands of parts per million (ppm) as a trace constituent in some natural materials. Zircon is widely used to date crystallization of igneous rocks and to provide ages of grains in sediments. Less commonly, other "accessory" minerals, such as monazite and titanite (sphene), are dated by U-Pb. Geological applications include determining ages of granite and other types of plutonic rock bodies, volcanic ash beds, metamorphic recrystallization of rocks, and formation of metallic ore deposits, as well as ages of individual sand grains that have been deposited by water and wind. The SHRIMP-RG's high mass-resolving power allows key trace element concentrations in accessory minerals to be determined in rou-

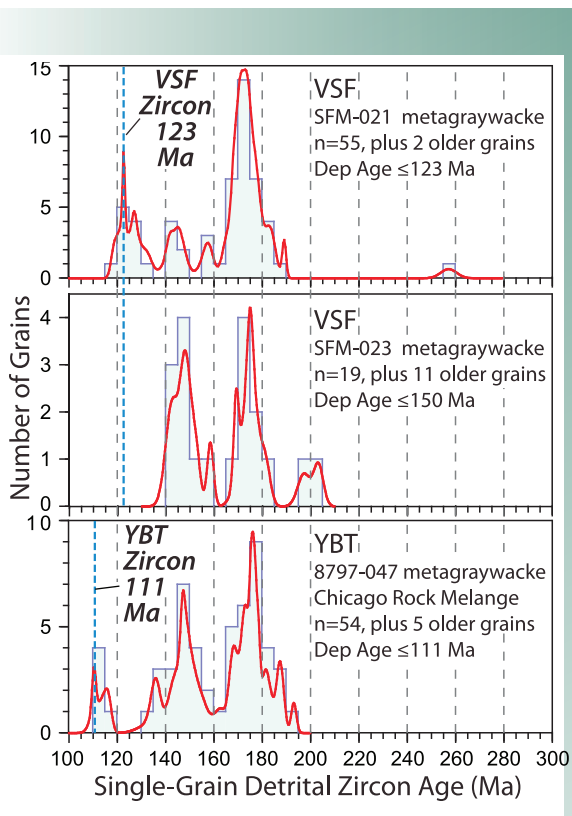

\section{Uranium-Lead Ages of Detrital Zircons}

Single-grain detrital zircon uranium-lead (U-Pb) ages, plotted as histograms (pale blue) and as probability density distributions ("age spectra," red curves), for three samples of metamorphosed sandstone from the Franciscan Complex of northern California, which was accreted to the continent by Cretaceous subduction of the Farallon Plate. The maximum depositional age of each sandstone is given by the youngest zircons (for example, Dep Age $\leq 123 \mathrm{Ma}$ ). Vertical dashed blue lines are maximum depositional ages from youngest dated zircon for Valentine Spring Formation (VSF) and Yolla Bolly Terrane (YBT). Major age peaks reflect sources within the Sierra Nevada magmatic arc. Modified after figures $5 d-f$ of Dumitru and others (2010). 


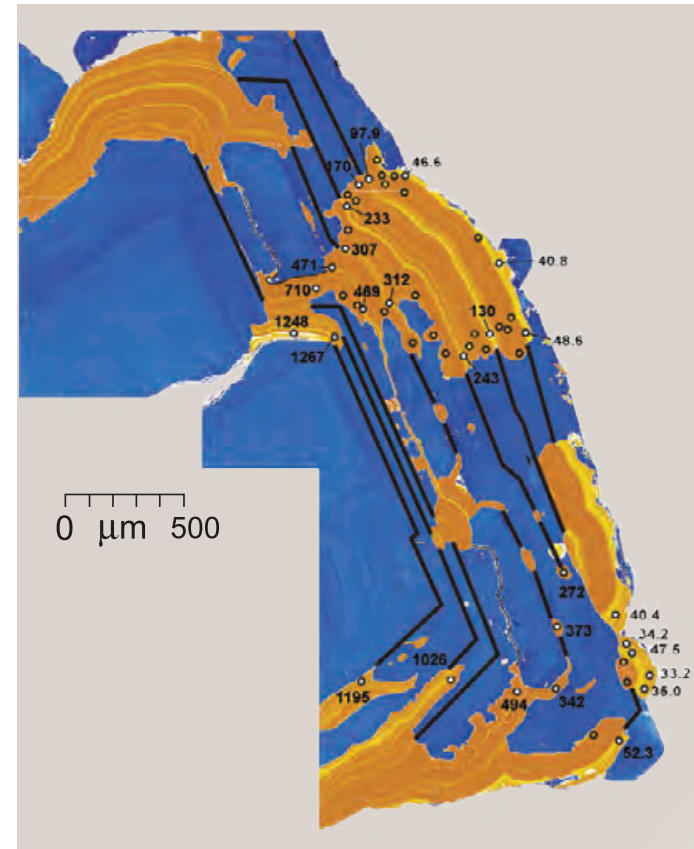

\section{Uranium-Series Geochronology of} Opaline Silica

False-color cathodoluminesence image of the tip of a secondary hydrogenic calcite blade from the deep vadose zone at Yucca Mountain, Nevada, showing growth layering in opal (orange) and calcite (blue). Circles show locations of spots analyzed for uranium-series (U-series) dating along with ages, in thousands of years (ka), for bright, U-rich layers that formed during drier interglacial periods. Black lines drawn along growth surfaces in calcite correlate opal layers with similar $\mathrm{U}$ concentrations and ages. The average mineral growth rate of $\sim 1.54 \mu \mathrm{m} /$ ky for opal in the upper central part of the image remained uniform over at least the past 300 ky despite large climatecontrolled fluctuations in effective surface moisture. After graphical abstract from Paces and others (2011), with permission from Elsevier. tine $\mathrm{U}-\mathrm{Pb}$ geochronology sessions, "fingerprinting" compositional populations and revealing origins of these minerals. The useful range of geochronology with the SHRIMP$\mathrm{RG}$ is extended to the recent past (less than a few hundred thousand years) by uranium-series disequilibrium dating, in which ${ }^{238} \mathrm{U}$ and geologically short-lived U and thorium (Th) daughter products in the decay chain $\left({ }^{234} \mathrm{U}\right.$, ${ }^{230} \mathrm{Th}$ ) are measured to determine the time since disturbance of a geochemical system, such as precipitation of silica $\left(\mathrm{SiO}_{2}\right)$ from groundwater onto rock surfaces or growth of zircon in magma erupted from a volcano. Dating hydrogenic silica (opal) by SIMS was developed at SUMAC, where new methods are constantly under investigation - recently U-series geochronology of igneous accessory minerals allanite and chevkinite.

\section{Trace Element Geochemistry}

In sessions devoted to measurement of elemental concentrations, most of the periodic table of elements is accessible with the SHRIMP-RG for abundances from parts per million (ppm) to parts per billion ( $\mathrm{ppb}$ ). Because secondary ion yield varies with the kind of material being analyzed (known as the matrix effect), the laboratory has developed a set of mineral and glass standards for accurate calibration of trace element concentrations. Concentrations of many trace elements from lithium (atomic number 3) to uranium (atomic number 92) may be determined in a single analytical routine for several common minerals and volcanic glass. Many specialized applications have been pursued with the SHRIMP-RG. Crystallization temperatures of zircon, quartz, titanite, and rutile are revealed by analysis of trace amounts of titanium in zircon and quartz and of zirconium in titanite and rutile, using recently published calibrations of the temperature dependence of these con- centrations in minerals. The natural glass particles in volcanic ash beds can be "fingerprinted" by trace element concentrations and these then used to match ash samples from widely separated localities. Additionally, trace element concentrations in minerals can be used, again through published calibrations, to infer chemical compositions of magma or fluid in which the crystals grew. Concentrations of "volatiles," such as water, carbon dioxide, sulfur, fluorine, and chlorine, dissolved in volcanic glass droplets trapped in crystals ("melt inclusions") give invaluable information on magma properties and can yield the depth at which magma resided before a volcanic eruption.

\section{Isotopes and Trace Elements in Biological Materials}

In research employing the SHRIMP-RG on biological calcium carbonate, such as coral, mollusc shells, and ear stones of fish (otoliths), trace concentrations of certain elements indicate the salinity and composition of the water in which the animal lived. In some cases, trace elements have been used not only to infer water chemistry but also temperature, such as in coral. One early SHRIMP-RG study measured isotopic ratios of strontium $\left({ }^{87} \mathrm{Sr} /{ }^{86} \mathrm{Sr}\right)$ in salmon otoliths, which grow in daily increments, to determine migration histories of juvenile fish.

\section{Geological "Thermometry"}

Scanning electron microscope (SEM) image of polished thin section of a metamorphosed (recrystallized) sedimentary rock from the Peninsular Ranges of southern California. In this backscattered-electron (BSE) image, brightness is proportional to the average atomic number of the material; that is, minerals rich in iron $(\mathrm{Fe}$, atomic number 26) are brightest and minerals rich in silica $\left(\mathrm{SiO}_{2}\right.$, atomic numbers 14 and 8 ) are darkest. This specimen illustrates progressive textural development of muscovite (Ms) + quartz (Qtz) symplectite and quartz + plagioclase (PI) myrmekite (types of mineral intergrowths) in response to changing temperature during metamorphism. $\mathrm{M}$, matrix; S, symplectite; Bt, biotite; Kfs, potassium feldspar. Circles indicate both location and size of ion beam spots. Colors indicate temperatures during mineral growth calculated from trace titanium concentration in quartz. Scale bar in upper left is 50 micrometers $(\mu \mathrm{m})$ long. After Peterman and Grove (2010, figure 2B).

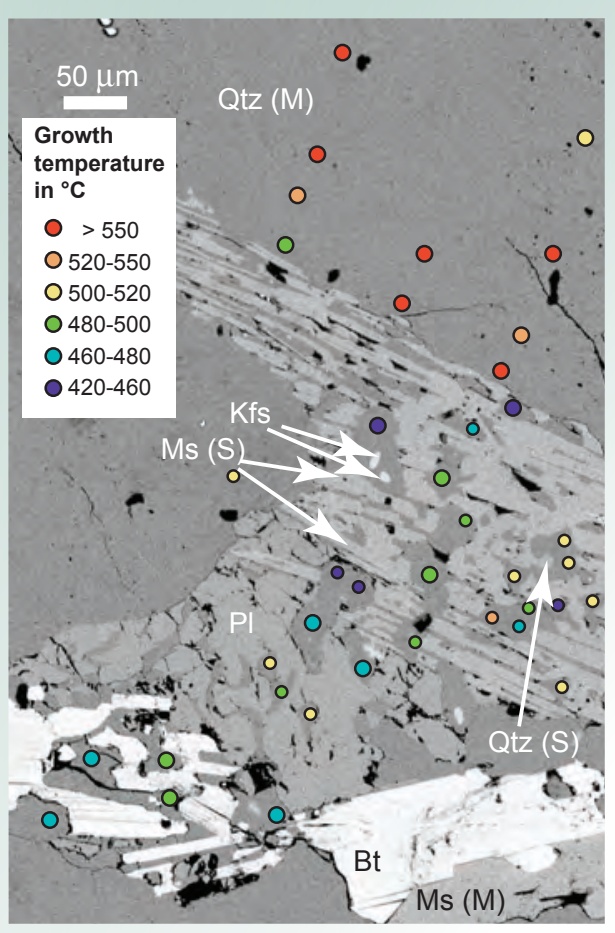




\section{Future Science at SUMAC}

Advancing geochronology across a broad spectrum of geological environments will continue to be a principal occupation of the Stanford-USGS SHRIMP-RG. Similarly, types of trace element concentration measurements will expand. SUMAC encourages new applications of the SHRIMP-RG for which it can be a useful tool. In U-Th-Pb geochronology and for many trace element applications, the SHRIMP-RG uses a negatively charged oxygen ion primary beam to yield positively charged secondary ions to the mass spectrometer. In 2012, a major investment in new equipment will greatly facilitate use of the SHRIMP-RG for analysis of elements such as carbon and sulfur that are most efficiently measured as negatively charged secondary ions produced by sputtering with a positively charged cesium ion primary beam.

\section{A Selection of Recent Publications Featuring Data From the Stanford- USGS SHRIMP-RG}

For a complete bibliography of more than 350 citations, visit http://shrimprg.stanford.edu.

\section{Regional Geology and Tectonics}

Bacon, C.R., Vazquez, J.A., and Wooden, J.L., 2012, Peninsular terrane basement ages recorded by Paleozoic and Paleoproterozoic zircon in gabbro xenoliths and andesite from Redoubt Volcano, Alaska: Geological Society of America Bulletin, v. 124, p. 24-34.

Barth, A.P., Wooden, J.L., Coleman, D.S., and Vogel, M.B., 2009, Assembling and disassembling California; A zircon and monazite geochronologic framework for Proterozoic crustal evolution in southern California: Journal of Geology, v. 117, 221-239.

\section{Sediment Provenance and Sedimen- tary Rocks}

Dumitru, T.A., Wakabayashi, J., Wright, J.E., and Wooden, J.L., 2010, Early Cretaceous (ca. $123 \mathrm{Ma}$ ) transition from nonaccretionary behavior to strongly accretionary behavior within the Franciscan subduction complex: Tectonics, v. 29, TC5001, doi:10.1029/2009TC002542.

Egger, A.E., Colgan, J.P., and York, C., 2009, Provenance and palaeogeographic implications of Eocene-Oligocene sedimentary rocks in the northwestern Basin and Range: International Geology Review, v. 51, p. 900-919.
Paleohydrology and Paleoclimate

Maher, K., Wooden, J.L., Paces, J.B., and

Miller, D.M., 2007, ${ }^{230} \mathrm{Th} / \mathrm{U}$ dating of surficial deposits using the ion microprobe (SHRIMP$R G)$; a microstratigraphic perspective: Quaternary International, v. 166, p. 15-28.

Paces, J.B., Neymark, L.A., Whelan, J.F., Wooden, J.L., Lund, S.P., and Marshall, B.D., 2010, Limited hydrologic response to Pleistocene climate change in deep vadose zones - Yucca Mountain, Nevada: Earth and Planetary Science Letters, v. 300, p. 287-298.

\section{Mineral Crystallization Temperatures}

Grujic, D., Stipp, M., and Wooden, J.L., 2011, Thermometry of quartz mylonites; Importance of dynamic recrystallization on Ti-in-quartz re-equilibration: Geochemistry, Geophysics, Geosystems, v. 12, Q06012, doi:10.1029/2010GC003368.

Peterman, E.M., and Grove, M., 2010, Growth conditions of symplectic muscovite + quartz; Implications for quantifying retrograde metamorphism in exhumed magmatic arcs: Geology v. 38, p. 1071-1074.

\section{Mineral Resources}

Vikre, P., Browne, Q.J., Fleck, R., Hofstra. A., and Wooden, J., 2011, Ages and sources of components of $\mathrm{Zn}-\mathrm{Pb}, \mathrm{Cu}$, precious metal, and platinum group element deposits in the Goodsprings District, Clark County, Nevada: Economic Geology, v. 106, p. 381-412.

Winter, L.S., Tosdal, R.M., Mortensen, J.K., and Franklin, J.M., 2010, Volcanic stratigraphy and geochronology of the Cretaceous Lancones Basin, northwestern Peru; Position and Timing of VMS: Economic Geology, v. 105, p. 713-742.

\section{Geochronology and Geochemistry of Igneous Rocks}

Barth, A.P., and Wooden, J.L., 2010, Coupled elemental and isotopic analyses of polygenetic zircons from granitic rocks by ion microprobe, with implications for melt evolution and the sources of granitic magmas: Chemical Geology, v. 277, p. 149-159.

du Bray, E.A., Bacon, C.R., John, D.A., Wooden, J.L., and Mazdab, F.K., 2011, Episodic intrusion, internal differentiation, and hydrothermal alteration of the Miocene Tatoosh intrusive suite south of Mount Rainier, Washington: Geological Society of America Bulletin, v. 123, p. 534-561.
Magma Evolution Beneath Volcanoes

Carley, T.L., Miller, C.F., Wooden, J.L., Bindeman, I.N., and Barth, A.P., 2011, Zircon from historic eruptions in Iceland; Reconstructing storage and evolution of silicic magmas: Mineralogy and Petrology, v. 102, p. 135-161.

Claiborne, L.L., Miller, C.F., Flanagan, D.M., Clynne, M.A., and Wooden, J.L., 2010,

Zircon reveals protracted magma storage and recycling beneath Mount St. Helens: Geology, v. 38, p. 1011-1014.

Wilson, C.J.N., and Charlier, B.L.A., 2009, Rapid rates of magma generation at contemporaneous magma systems, Taupo volcano, New Zealand; insights from U-Th model-age spectra in zircons: Journal of Petrology, v. 50, p. 875-907.

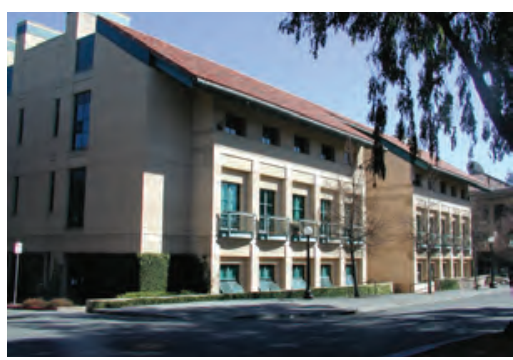

The Stanford-USGS SHRIMP-RG is housed in the basement of the Green Earth Sciences Research Building at Stanford University.

Charles R. Bacon ${ }^{1}$, Marty Grove ${ }^{2}$, Jorge A. Vazquez, and Matthew A. Coble ${ }^{4}$

${ }^{1}$ SUMAC Co-Director, U.S. Geological Survey

${ }^{2}$ SUMAC Co-Director, Stanford University

${ }^{3}$ Staff Scientist, U.S. Geological Survey

${ }^{4}$ Staff Scientist, Stanford University

Edited by Peter H. Stauffer

Graphic design by Judy Weathers

Any use of trade, product, or firm names is for descriptive purposes only and does not imply endorsement by the U.S. Government.
For more information contact: Charles R. Bacon
U.S. Geological Survey, MS 910
345 Middlefield Road
Menlo Park, CA 94025
Tel. (650) 329-5246
cbacon@usgs.gov
Marty Grove
Department of Geological and
Environmental Sciences
Stanford University
Stanford, CA 94305
Tel. (650) 721-5490
mjgrove@stanford.edu
http://shrimprg.stanford.edu

This Fact Sheet and any updates to it are available online at http://pubs.usgs.gov/fs/2012/3067/. 